\title{
Providing Economic Incentives for Biodiversity Conservation in an Emerging Bioregional Context
}

\author{
Edwin Muchapondwa ${ }^{1}$, Harry Biggs ${ }^{2}$, Amanda Driver ${ }^{3}$, Frank Matose ${ }^{4}$, Eric Mungatana ${ }^{5} \&$ Kelly Scheepers ${ }^{6}$ \\ ${ }^{1}$ School of Economics, University of Cape Town, Cape Town, South Africa \\ ${ }^{2}$ South African National Parks, Skukuza, South Africa \\ ${ }^{3}$ South African National Biodiversity Institute, Pretoria, South Africa \\ ${ }^{4}$ Department of Sociology, University of Cape Town, Cape Town, South Africa \\ ${ }^{5}$ Centre for Environmental Economics and Policy in Africa, University of Pretoria, Pretoria, South Africa \\ ${ }^{6}$ South African National Parks, Kimberley, South Africa \\ Correspondence: Edwin Muchapondwa, School of Economics, University of Cape Town, Private Bag X3, \\ Rondebosch 7701, South Africa, Tel: 27-21-650-5242. E-mail: Edwin.muchapondwa@uct.ac.za
}

\author{
Received: August 26, 2012 Accepted: October 22, 2012 Online Published: October 31, 2012 \\ doi:10.5539/jsd.v5n11p118 URL: http://dx.doi.org/10.5539/jsd.v5n11p118
}

The research is financed by Economic Research Southern Africa (ERSA), FORMAS and Swedish International Development Cooperation Agency (Sida). An earlier version of this article appears as ERSA Working Paper No. 120

\begin{abstract}
Many protected areas are not successfully conserving biodiversity, often despite adequate management within their borders. Changes in land use outside protected areas can alter ecological function inside protected areas and result in biodiversity loss given that protected areas are almost always parts of larger ecosystems. Economic incentives are seen as one of the most promising avenues to influence conservation goals. This paper deals with enabling these in the now commonly accepted notion of bioregional landscape management. We suggest a holistic framework to help understand where and how such incentives may function. We then discuss a range of desired incentives, and relate as many of these as possible to potential underlying institutional changes. Without going into country-specific details, several southern African examples are used, all the while relating both principles and examples to bioregionalism. We conclude that incentives for bioregional conservation in southern Africa are far more likely to succeed if key institutions can be introduced.
\end{abstract}

Keywords: biodiversity conservation, bioregions, economic incentives, institutions, mainstreaming

\section{Introduction}

Biodiversity (Note 1) conservation has traditionally taken place within the framework of protected areas. However, authors such as Hansen and DeFries (2007) observe that many protected areas are not successfully conserving biodiversity, often despite adequate management within their borders. They suggest that the major reason for this could be the expansion and intensification of land use in the areas adjoining the protected areas. Changes in land use outside protected areas can alter ecological function inside protected areas and result in biodiversity loss given that protected areas are almost always parts of larger ecosystems.

Indeed, the concept of ecosystem management grew from the goal of managing regional landscapes to maintain the ecological integrity of the protected areas that they contain. Since the early 1970s, UNESCO has advocated the management of the lands around protected areas along a gradient of decreasing intensity of use towards the protected area boundaries. The traditional conservation approach appears to assume that protected areas alone are capable of meeting biodiversity targets (Note 2) and therefore that merely guaranteeing their persistence is sufficient to meet biodiversity targets. Today we know there are many conservation priority areas outside of, often even far from, protected areas. Also, the total size of area under conservation-friendly land use of one or another kind may be functionally crucial. Thus, for successful biodiversity conservation, there is need for bioregional management, where the region in question encompasses protected partially protected or unprotected 
portions of ecosystems. For the purposes of this paper, a bioregion is simply either an agglomeration of, for instance, districts at a sub-national scale, or an agglomeration of bigger areas at an adjacent but international scale, with some reason for being considered together (Note 3).

Good management inside the protected area may be relatively easy to achieve, but managing outside the protected area requires ways to tackle heightened complexity. Merely applying protectionist strategies outside protected areas, as inside the protected areas, will most likely not guarantee the achievement of biodiversity goals and targets, due to the presence of other competing land uses. Indeed, the biodiversity research community has responded to the challenge of biodiversity conservation outside protected areas by calling for mainstreaming biodiversity conservation in society generally (Cowling, 2005). Mainstreaming entails changing the behavior of individuals and organizations to adopt norms, values, and practices which promote biodiversity whenever they make decisions that are likely to affect it. Most often, this takes place outside of protected areas. The widely cited mechanism of mainstreaming is effective communication of the issues to key stakeholders (Cowling, 2005).

The most effective mechanism of mainstreaming may well be the modulation of economic conditions of individuals and organisations, since biodiversity conservation can ultimately be seen as an economic issue for two basic reasons. Firstly, biodiversity is a component of natural capital, an ecosystem service (or set of services) in its own right, as well as being related to the flow of other valuable ecosystem goods and services (such as say water flow, soil nutrient cycling, medicinal plants, recreational services); on both these scores a source of economic wellbeing (Millennium Ecosystem Assessment, 2005; Blignaut \& Aronson, 2008). Secondly, the extent of biodiversity conservation outside protected areas is largely guided by the norms, values and practices of market economies which promote the pursuit of economic optimization objectives.

A potentially effective mechanism for mainstreaming biodiversity conservation might thus be the use of economic incentives. Economic incentives refer to mechanisms that change the behaviour of actors with respect to economic choices by altering their economic conditions (Note 4). Economic incentives are potentially capable of binding actors to support norms, values, and practices that promote biodiversity persistence. This paper seeks to identify incentives of particular relevance to the bioregional context, then unravel the ways through which these economic incentives can be used to enhance biodiversity conservation. It examines the possibility that particular institutional arrangements in society may significantly enhance the chances of establishing or supporting effective incentives in a bioregion. It helps prepare for this examination of incentives and underlying institutions by presenting what is a widely-applicable generic framework, providing a backdrop for helping understand the linkages between incentives/institutions and broader components, states and happenings in society, and helps keep focus on the bioregional theme of this paper.

The structure of the paper is as follows. Section 2 suggests the conceptual framework for helping position and understand factors affecting biodiversity conservation in bioregions, and the role of incentives/institutions in this. Section 3 looks at the role of economic incentives relating them specifically to effective bioregionalism. In section 4, institutions are singled out as one important class of socioeconomic arrangements directly associated with these economic incentives and likely to be a major determinant (again specifically in bioregional context) of the vulnerability or success of biodiversity conservation. Section 5 acts as a conclusion and describes a way forward.

\section{The Conceptual Framework for Studying the Factors Affecting Biodiversity in Bioregions}

The success of biodiversity conservation in a bioregion will depend on the de facto sector allocation, and the configuration of the land use mosaic in that bioregion. A number of different land uses including 'pure' conservation, crop agriculture, livestock farming, natural resource harvesting, rural settlements, urban centers, logging, mining, other commercial industries, etc can comprise the land use mosaic. The land use mosaic reflects people's value systems and management choices in response to a range of social, technological, ecological, economic and political driving factors (Biggs et al., 2004; DeFries et al., 2007). Thus, ultimately the extent of biodiversity conservation in a bioregion depends on a myriad of factors affecting land use decisions by a collection of stakeholders. In this section we present a conceptual framework for exploring the factors that influence the configuration of the land use mosaic in a bioregion and therefore also biodiversity conservation in that bioregion (see Figure 1, Note 5). The purpose of this framework is to keep a useful bigger context in mind as we go ahead and describe incentives and institutions, thus seeing where they fit in, and what prerequisites and consequences they might have. It will also assist to some extent in keeping our focus on the bioregional theme.

As indicated earlier, the configuration of a land use mosaic (Figure 1, Box 1.1) and therefore biodiversity conservation in that mosaic is shaped by a range of factors. The land use mosaic itself shows important 
dimensions in space (from smaller, like many national parks) to larger (like a transfrontier conservation area) and time (from short to long-term, and current to future perspectives). Within the localized socio-ecological-economic system, these land use dynamics are determined by (i) people's assets in the form of the different types of capital they have at their disposal at any given time (Figure 1, Box 1.2), (ii) the various systems of tenure which underpin the land use mosaic (Figure 1, Box 1.3), (iii) the extent of regional development (Figure 1, Box 1.4), and (iv) the economic approaches used in decision making (Figure 1, Box 1.5).

People's asset registry consists of ecological, financial, physical, human and social capital (Scoones, 1998; DFID, 1999), as well as cultural capital (Figure 1, Box 1.2). Ecological capital includes the range of direct and indirect, tangible and intangible ecosystem goods and services (Millennium Ecosystem Assessment, 2003; Kumar, 2005), including the service of biodiversity perceived by some. The other capitals (Kumar, 2005) play an equally important role - financial (e.g. cash, savings, investments); physical (e.g. infrastructure, telecommunications, transport), social (e.g. networks, trust), human (e.g. capacity of skills and expertise) and cultural (e.g. traditions, belief systems). Human values are amongst the strongest factors in ultimately influencing land-use patterns, and an effective interface (Figure 1, Box 1.2) which engages them from the outset in a meaningful way, has become an important success factor (Knight et al., 2008), with resilience of systems (Bohnet \& Smith, 2007) becoming an important counter-consideration to unbridled short-term economic returns.

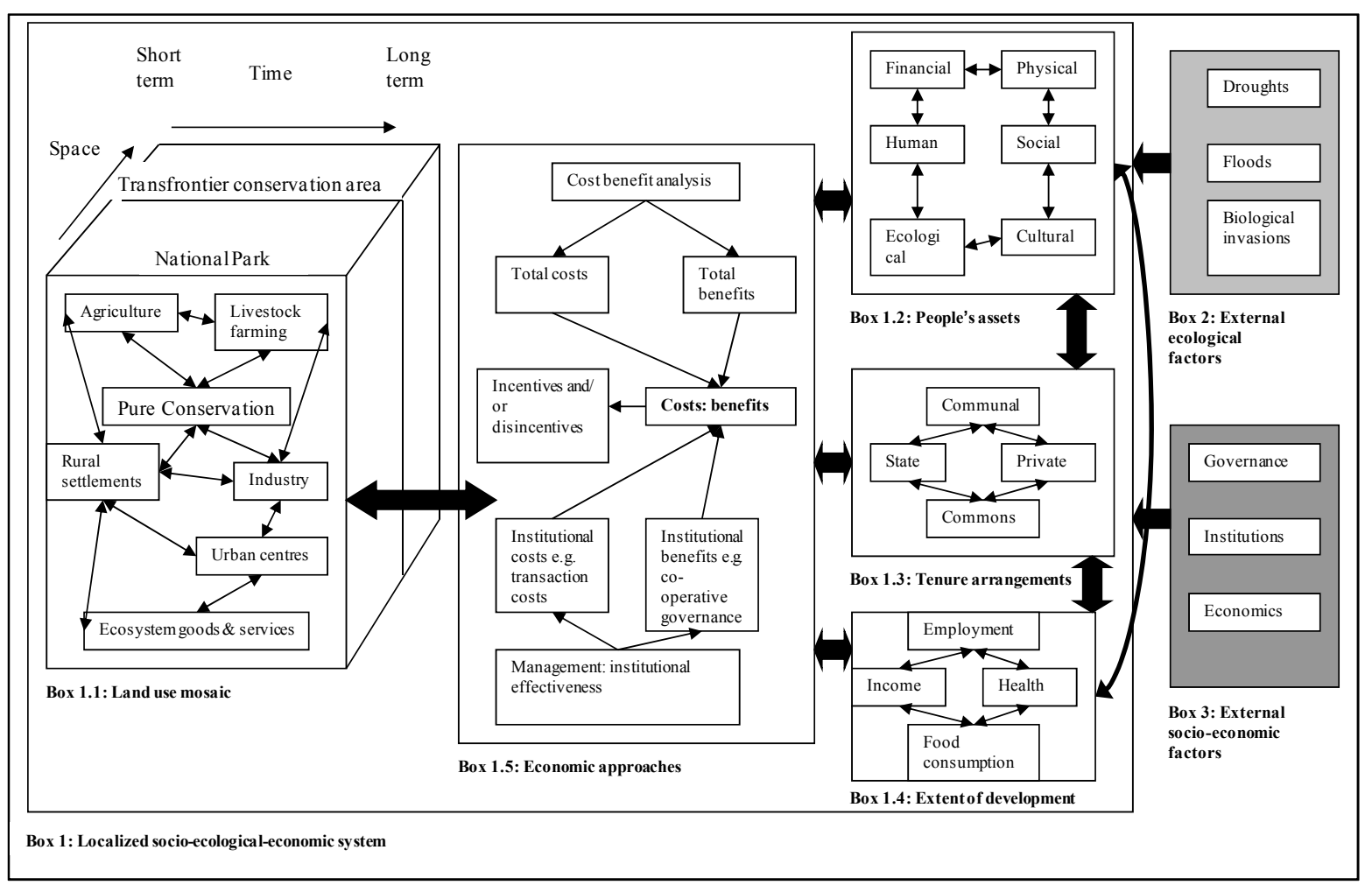

Figure 1. Conceptual framework for understanding the factors affecting biodiversity conservation in bioregions

Any development opportunities are subject to institutional constraints in terms of formal laws of access and use rights to land and resources, as well as informal rules, taboos or codes of conduct, particularly with regard to traditional leadership and natural resource management practices (Oström, 1990; Grundy \& Michell, 2004). Hence, this framework recognizes four major types of tenure which span rural, urban and peri-urban settings, all of which may occur within a particular bioregion. They are state-owned land, communal land, private land and commons (Figure 1, Box 1.3).

It is important to understand how resources flow between these various types of tenure arrangements within a bioregional land use mosaic to promote its sustainable development (Oström, 1990; World Resources Institute, 2005). Joint venture partnerships between the state, local communities and the private sector, encourage such a cross-flow of resources between different stakeholders and across different tenure arrangements (i.e. state, communal and private) to promote conservation, local economic empowerment and capacity building. For 
example, new legislation on forests in South Africa makes allowances for the Participatory Forestry Management (PFM) of state and indigenous forests (Grundy \& Michell, 2004; Willis, 2004). This necessitates granting local communities access to state forests for the harvesting of ecosystem goods and services to reduce poaching, as well as the state providing an extension service to local communities to empower them to better use and manage their own forests. The private sector partners often play an important role in the training and capacity building of local communities, and help connect them to formal product markets.

People's asset registry can also interact with the land tenure system to influence land ownership and land use practices (Gupta, 1999; Lebel et al., 2006). For example, local communities with strong cultural capital and identity may be more likely to engage in conservation and/or nature-based tourism activities that build on this asset (e.g. cultural villages) than more 'western' tourism initiatives. In contrast, the Makuleke land claim on part of the Kruger National Park witnessed the local community invest in a luxury game lodge and wildlife safaris, arguably at the expense of their local culture (Reid \& Turner, 2004).

The extent of regional development, measured by indicators such as income, employment, health and food consumption (Figure 1, Box 1.4), impacts on the land use mosaic (Biggs et al., 2004), and feeds back to strengthening or weakening the asset base and making people more or less vulnerable to external factors (Meinzen-Dick \& Adato, 2001). The challenge remains that of providing incentives for land uses complementary to conservation, and disincentives for land uses conflicting with conservation within the bioregion when land uses are expected to achieve regional development targets. Thus the configuration of the land use mosaic may be driven by the need to achieve a set of goals which extend beyond just biodiversity conservation. For example, along the southern Cape coast of South Africa, the coastal forests of Tsitsikamma National Park and Wilderness National Park are managed for biodiversity conservation, small scale timber logging and the sustainable use of non-timber forest products by local communities. The downstream benefits from timber logging only include USD580 000 year $^{-1}$ in taxes to the state, a contribution of USD200 000 year $^{-1}$ to the regional gross domestic product and 640 jobs, which ultimately contributes to poverty alleviation, improved incomes and increased food security (Armin Seydack, personal communication).

The framework also assumes that there is a set of economic approaches that landowners and users consult as rules of thumb to guide their land use decisions (Figure 1, Box 1.5). The first heuristic is that the benefits of an intervention, land use or development initiative must outweigh the costs, and the second rule is that any type of intervention needs to be cost-effective in achieving the desired goal. Borrowing from conventional consumer economic theory, approaches such as environmentally-adjusted cost benefit analysis and the assessment of the cost effectiveness of institutions that underpin people's land use decisions can help to identify incentive and disincentive mechanisms for enhancing biodiversity conservation. Environmentally-adjusted cost benefit analysis quantifies, as far as is possible, the total benefits and costs (i.e. ecological, economic, physical, human, social and cultural) from practicing a particular land use. It is the trade-off between the costs and benefits that determines people's land use decisions, where the option that yields 'good enough' net benefits is favored over others (Sent, 2004).

This framework draws on the theory of bounded rationality, and assumes that landowners and users refer to a stable set of rules of thumb by which to make their land use decisions, acting with incomplete knowledge, towards meeting a specific target (near but not necessarily the optimal choice) (Gans, 1996; Sent, 2004). Therefore, the user's learning involves changing their choices on the basis of past outcomes to move nearer towards optimality (Sent, 2004). If the rules work well, they are retained and refined by the user whereas if the rules work poorly, they are used less and less, and eventually abandoned (Aumann, 1997).

It must also be acknowledged that other external factors can impact on biodiversity conservation in the bioregion (Biggs et al., 2004). External ecological factors (Figure 1, Box 2) including natural disasters such as droughts, floods, biological invasions and climate change can have direct impacts on land use choices and biodiversity conservation outcomes. External socio-economic factors (Figure 1, Box 3) including political change (e.g. change in the ruling party), economic change (e.g. change in market prices) and institutional change (e.g. emergence of new institutions and power players) can influence tenure arrangements, development opportunities and land use options. Here, we can also mention other stakeholders such as private companies and industry who can play a proactive role in a bioregion located far away from them. Private companies and industry can be key drivers of change in the bioregion through their decision-making processes which often take place outside of the physical bioregion. Examples include how certain mining companies could influence certain bioregions through their efforts to go the "green" route and how some polluting and water-intensive industries (e.g. breweries) could work towards water-neutrality and bring changes to a remote bioregion. 
Other key elements of the framework are that it is dynamic through space and time (Gunderson \& Holling, 2002), inclusive of formal and informal conservation (e.g. conservation ranging from formal protected areas to local taboos over protected or sacred forests) and embraces the principles of adaptive management (Biggs \& Rogers, 2003) acknowledging multiple sustainable development options and strategies for a particular region. On the scale issue, the relative importance of the ecological, social and economic components may differ across scales. For example, at the scale of a park, ecological objectives such as conserving, or in some cases, restoring ecosystem functions and processes and promoting habitat heterogeneity may take precedence over social objectives such as maximizing the tourist experience, or economic objectives such as ensuring that the park is financially self-sustaining (Du Toit, Rogers \& Biggs, 2003; Note 6).

How are incentives and institutions, as we have defined them, actually related? An incentive can be seen, in its most simple form in the context of this paper, as a stand-alone instrument. For instance, if we refer to a tax, a subsidy, or a price, then each of these illustrative incentives can be looked at on its own, and it is conceivable that if we introduce or alter these incentives that this might be done without looking any further in society as to how other context might influence its application. As long as the incentive is effective, we may not take a deeper or systemic interest in why it is effective. In the case of establishing a price, we may have to take a deeper interest, because it may be a prerequisite that, for instance, property rights need to be defined before a price becomes a de facto reality. We call the broad rule which regulates how people interact (such as open access, clearly defined private rights, clearly defined state rights, or clearly defined community rights) an institution.

This paper seeks to examine, as in the case of price above, which underlying broad arrangements (institutions) in society bring to life, favour or enable which of the various immediate motivators (incentives). If indeed switching the underlying institutions (in this paper say changing between open access, clearly defined private rights, clearly defined state rights, or clearly define community rights) proves enabling for certain individual (or particular bundles of) incentives, then we will have found an underlying single (or easier or more durable) instrument likely to help us get those incentives operational.

\section{The Role of Economic Incentives in Biodiversity Conservation in a Bioregion}

As shown in the framework in Figure 1, the decision about land use is made within particular economic approaches which assess the economic incentives or disincentives generated by a range of factors. Thus, what makes biodiversity conservation a preferred land use is the structure and magnitude of economic incentives associated with it in the range of factors that landowners and users consider in land use choice. As such, the way to affect the land use choices would be to tweak the economic conditions which landowners and users experience. This section unravels the range of economic incentives that can be used to influence the land use choices in favor of biodiversity conservation.

Biodiversity conservation has tended to be unsuccessful because (i) it usually has "public good" characteristics of non-excludability and indivisibility, which makes its provision prone to free-riding behavior, (ii) economic agents interact with biodiversity through various systems of tenure such as "open access", which usually creates incentives for accelerated rates of use due to the lack of assurance that biodiversity resources saved in the present will be available in the future, and (iii) biodiversity might not, in an financial sense, compete successfully against other land uses which offer better livelihood options. It is also believed that poor biodiversity conservation has resulted because conventional economic approaches have been unable to capture its 'true' value, and the approaches are often limited to situations where ecosystems are relatively intact and functioning properly (Emerton, 2001a; Fabricius et al., 2004; Note 7).

The threat of the possibility of (i) free riding behavior, (ii) open access tenure, (iii) failure of biodiversity to provide livelihoods, and (iv) the use of non-comprehensive economic approaches, together create the need to constrain human and enterprise actions with regards to their interaction with biodiversity. One could do this by use of (i) command-and-control or (ii) economic incentives. Each of these options is likely to be better in particular circumstances - it mainly depends on the nature of the threat to biodiversity. However, while a command-and-control system imposes certain restrictions on people's access to, and use of resources, in a top-down approach, economic incentives work with human behaviour to influence people's land use choices in a more subtle manner akin to a bottom-up approach. Consequently, the former requires greater enforcement and policing than the latter. The more biodiversity is conserved through economic incentives, the more resources are thus freed up from general command-and-control efforts to conserve economically unviable but ecologically important ecosystems through more effort-intensive but necessary command-and-control options.

Economic incentives which increase the perceived magnitude of benefits from biodiversity conservation accruing to landholders and increase the costs of alternative land uses (e.g. crop farming, livestock farming, 
industry, mining, settlements) are required in order to level the playing field in a bioregion. Thus, economic incentives need to overcome the sources of biodiversity conservation market failures. A number of different economic incentives have been applied in different contexts with either direct or indirect linkages to conservation.

The economic incentives which will be appropriate for enhancing biodiversity conservation in a bioregional context are those which can use information about alternative land uses. These include (i) the creation of markets to reward biodiversity conservation, (ii) the sharing of revenue from biodiversity components with other conservation stakeholders, (iii) the provision of grants for local development and infrastructure to reward for biodiversity conservation's positive externalities, (iv) the provision of subsidies for biodiversity conservation activities, (v) the granting of tax concessions for biodiversity conservation, (vi) the elimination of perverse subsidies negating biodiversity conservation, (vii) the creation of biodiversity offsets, and (viii) the set up of conservation easements (Ashley, 1996; Secretariat of the Convention on Biological Diversity, 2001; Emerton, 2001b; Kumar, 2005; Tisdell, 2004; Millennium Ecosystem Assessment, 2005). Table 1 gives expanded versions of these economic incentives.

Table 1. Typology of economic incentives applicable to bioregions

Type of incentive

The creation of markets to reward biodiversity conservation (stimulating underdeveloped or inaccessible biodiversity product markets, say, through the promotion of value-adding activities such as trophy hunting and up-market tourism and payment for ecosystem services),

The sharing of revenue from hunting concessions with other conservation stakeholders and the provision of appropriate and adequate compensation for damages sustained from damage causing animals,

The provision of government, NGOs, and donor grants for local development and infrastructure to counter for biodiversity conservation's positive externalities not reflected in the market or the provision of voluntary contributions by other stakeholders for conservation efforts on land (agri-environmental payments for agricultural practices that contribute to the maintenance of species and ecosystems),

The provision of subsidies for the cost of habitat restoration, protection and conservation and the marketing of certain biodiversity components (where their value is still too low to make their conservation economically viable for a private landowner),

The granting of tax concessions for conservation activities on land (at least as generous as those allowed for alternate productive land uses),

The elimination of perverse subsidies that negate biodiversity conservation and taxes/user fees for activities with "external" costs to biodiversity and conservation levies (and, where possible, transfer of these subsidies to payments for non-marketed biodiversity conservation),

The establishment of biodiversity offsets (biodiversity banking, biodiversity trading, conservation banking),

The set up of conservation easements
Historical and emergent applications

Private landholders; CBNRM; industry; Municipalities; Park agencies

Private landholders; CBNRM; Municipalities

Private landholders; CBNRM; industry; Municipalities; Park agencies

Private landholders; CBNRM; industry; Municipalities; Park agencies; NGOs

Private landholders

Private landholders; CBNRM

Private landholders; Industry (e.g. Mining and Property Developers)

Private landholders 
The important aspect in the design of these economic incentives is that they should raise the rewards coming from biodiversity conservation relative to rewards coming from alternative land uses. Otherwise giving biodiversity conservation a reward which is isolated from rewards coming from alternative land uses might result in inadequate incentives to shift into more biodiversity conservation. Thus, in a bioregion, there is a risk that poorly designed economic incentives (i.e. those designed as if they are to be implemented in a one sector setting) might not encourage any biodiversity conservation at all due to other land uses still providing better opportunities. In a way, this discussion recognizes that biodiversity conservation has opportunity costs which are usually easier to value than biodiversity itself. For example, values of fracking in the Karoo area of South Africa can easily be derived by making use of valuation models with lesser limitations (e.g. no problem with discount rate, etc.) than those related to biodiversity valuation. Thus, proponents of biodiversity conservation need to take into account the opportunity cost of not developing the Karoo when designing incentives to promote biodiversity-friendly land uses in that area.

The economic incentives might themselves embody certain stimuli. However, the stimuli deriving from economic incentives will be perceived in various ways by the landowners and users. In order for the full stimuli of economic incentives to be experienced by landowners and users, it is essential that the economic approaches they use capture, as far as is possible, the 'true' value of the various land uses within a bioregion (Note 8). Sadly, most land use decisions involving biodiversity conservation are strongly influenced by the need for trade of some biodiversity components in formal markets such that the non-marketed biodiversity components are ignored (Millennium Ecosystem Assessment, 2005). These non-marketed biodiversity components are often high and sometimes more valuable than the marketed ones. In order to enhance biodiversity conservation, it is imperative that the values of biodiversity conservation experienced by decision making units be enhanced and that decisions be improved by considering the total economic value of alternative land uses. Land uses involving biodiversity conservation usually compare more favorably to alternative land uses after incorporating the true value of biodiversity (Note 9).

\section{The Importance of Institutions in Supporting the Role of Economic Incentives in Enhancing Biodiversity Conservation in Bioregions}

One class of socioeconomic arrangements which can potentially give rise to the realisation of the full stimuli of certain economic incentives is called "institutions". In this context, "institutions" refer to the laws, rules, codes of conduct, norms and strategies adopted by individuals operating within and across organisations; they exist in the minds of the participants, and are sometimes shared as implicit knowledge rather than in an explicit and written form (Oström, 1990). Institutions are directly associated with economic incentives but the link largely remains unexplored. Institutional arrangements confer a spectrum of rights over natural resources (see for example Hertzler, 2007; Note 10). Institutions influence the decisions for land use, investment, natural resource use and therefore biodiversity conservation. Institutions affect human livelihoods through influencing people's access to assets, livelihood strategies, vulnerability to external factors, and terms of exchange (Meinzen-Dick \& Adato, 2001). They operate across multiple spatial and temporal scales and within all spheres (i.e. public and private) to significantly influence biodiversity conservation outcomes.

With strong appropriate institutions, investment in biodiversity conservation improves as the financial value of biodiversity approaches its total economic value. There is a need to ensure that the institutional arrangements generate enough economic incentives for sound biodiversity conservation (Note 11). In the literature, the investigation of how institutions influence the decisions for land use and biodiversity conservation has focussed on the engagement of local communities in biodiversity conservation by protected area management. The centrepiece of this focus on the engagement of local communities in biodiversity conservation by protected area management can be described as the various initiatives aimed at decentralizing decision making with respect to the management of biodiversity (for example see Shyamsundar et al., 2005). The key decentralization strategies that have been used in protected areas and biodiversity conservation since the 1980s are the integrated conservation and development projects (ICDP's) and CBNRM, and many studies have assessed the successes and impacts these strategies have had on protected areas and biodiversity (Shyamsundar et al., 2005; Note 12). The ultimate goal has been for protected area managers to be able to influence land use decisions outside protected area boundaries. However, in a bioregional context, focus should be on the engagement of all stakeholders. Hence the protected area management is only one of the stakeholders in the bioregion. A range of institutions-based incentives have been employed in different contexts to encourage private landowners to support conservation and complementary land uses. These include (i) providing secure tenure (e.g. private rights to forest use and management), (ii) defining clear use rights (e.g. conditional use rights to use, hunt and sell wildlife on private land), (iii) improved tenure and use rights through the creation of communal conservancies, 
wildlife management areas and contractual parks etc. (Fabricius et al., 2004), (iv) promoting multiple use and best practice (e.g. use of eco-friendly methods) and (v) the promotion of joint venture partnerships (Ashley, 1996; Emerton, 2001b; Tisdell, 2004). In a bioregional context, the design of such institutional arrangements to enhance biodiversity conservation needs to take cognizance of its effect on alternative and adjacent land uses. Since many different landowners and users interact in a bioregional context, there might be a need to create new forums or organisations which take a wide view of the effects of institutional reforms on all alternative land uses in a bioregion.

A number of issues such as the large gap between private and public benefits, heterogeneity amongst stakeholders, tenure over biodiversity resources, financial sustainability and realignment of organisations need to be addressed alongside any proposals for institutional reform in a bioregion. Similar issues have been identified in the CBNRM context where a multitude of stakeholders also exist (Shyamsundar et al., 2005).

Biodiversity resources are associated with both the privately-appropriable benefits and public benefits of their continued existence. As alluded to earlier, most land use decisions involving biodiversity conservation are strongly influenced by the privately-appropriable benefits. If such economic approaches dominate private decisions about biodiversity conservation then the individual agent's private benefits from conservation would need to be large relative to their total income and/or public benefits from conservation. Thus, any proposals for institutional reform in a bioregion would need to ensure that the values of biodiversity conservation experienced by decision making units would be enhanced.

The landowners and users in a bioregion are characterised by heterogeneity of endowments, land uses and values. These differences may result in landowners and users suffering unequal costs and benefits emanating from any institutional change aimed at enhancing biodiversity conservation. Consequently, the differing stakeholder needs may contribute to conflict and impact biodiversity conservation efforts. Therefore, in the presence of extreme heterogeneity, compensation schemes might be needed to redistribute costs and benefits emanating from any institutional change aimed at enhancing biodiversity conservation.

Biodiversity conservation usually also generates public goods and, as a consequence, the state always has an interest in controlling the magnitude of this activity fearing the possibility of the proverbial market failure associated public goods. This is the reason why biodiversity conservation programs usually confer only usufruct rights to local stakeholders, while ownership rights remain with the state. Despite good reasons for this, there may also be reasons to be concerned about whether the lack of ownership will weaken biodiversity conservation efforts in the long run especially if landowners and users pursuing alternative land uses have both usufruct and ownership rights. Landowners and users might find it enticing to pursue alternative land uses rather than biodiversity conservation because alternatives give them more flexibility in fulfilling their objectives.

Financial sustainability - biodiversity conservation programs are generally not self-sustained. Support for these programs usually comes from tourism and international donors, which are often a function of agendas far beyond the control of local stakeholders. Thus, financial sustainability is an issue that each conservation area will need to confront.

Since many different landowners and users interact in a bioregional context, there might be a need to create new forums or organisations which take a wide view of the effects of institutional reforms on all alternative land uses in a bioregion. There might be a need for new organisations to address new threats emanating from any institutional change aimed at enhancing biodiversity conservation. The traditional institutional analysis has not concerned itself with big commercial interests such as agriculture, mining, property developers, etc. The major pressures on biodiversity outside protected areas, and in some cases inside them as well, also includes outright loss of natural habitat (from cultivation, mining, urban expansion, coastal development etc), flow modification (includes over-abstraction of water, also altering e.g. seasonal flow of rivers) and the negative effects of invasive alien species. In the South African context, these could actually be more significant than subsistence use of natural resources by local communities. The challenge then would be to investigate which institutions influence/regulate these major pressures. Competition or complementarity between new and old organisations is inevitable and needs to be taken into account.

At the national scale, in South Africa, institutions-based incentives have focused on (i) establishing appropriate institutions and lines of administration to manage finances such that funds are channeled where they are most needed and not 'trapped' in a national treasury, which is far removed from the management context, or reallocated for other purposes, (ii) providing secure tenure and use rights, (iii) capturing positive externalities from government conservation efforts, and (iv) promoting diverse livelihood options for the single landowner or user, as well as across regions (Ashley, 1996; Emerton, 2001b). Hence, government policies on land tenure may 
influence biodiversity conservation to a greater extent than biodiversity targets at the national scale. The land claims process in South Africa is such an example, and has been an effective mechanism by which local communities have re-acquired land formerly belonging to them, but from which they were forcibly removed during the Apartheid era. Where land claims have been awarded in national parks, this has often resulted in the establishment of contractual parks - a kind of joint venture partnership between government and local communities, whereby the management authority leases the land from the community (usually on a 99 year lease) and it remains within the national conservation estate, a joint management board is established with decision-making authority, and economic benefits generated from conservation and tourism-based activities on the land, as well as from conservation or tourism levies (in some instances), and channeled back into the community (Reid \& Turner, 2004).

\section{Conclusion}

This paper accepted that biodiversity conservation in southern Africa ought to take place both inside and outside protected areas in a bioregional approach if biodiversity targets are to be met. A framework for studying the factors affecting biodiversity conservation in bioregions was proposed and it suggested that a range of social, technological, ecological, economic and political factors drive biodiversity conservation in bioregions. The use of economic incentives was argued to be a potentially more effective mechanism for mainstreaming biodiversity conservation in bioregions, given that landowners are likely to respond to certain amenable economic approaches in making land use decisions, than command-and-control systems.

There are mainly two types of arrangements that can be used in economically incentivizing for biodiversity conservation; public fiscal payment and market-based instruments. The fiscal payments are prone to a number of shortcomings, such as high transaction costs, low efficiency in fund use and ambiguity in target beneficiaries e.g. funds for CBNRM projects are sometimes used for local economic empowerment and capacity building initiatives rather than to promote strong linkages between sustainable resource use, community benefits and conservation, which is the central principle of CBNRM. Another challenge is deciding whether indirect or direct payments for biodiversity conservation would be more effective. A price premium on environmentally sustainable and eco-friendly products is an example of an indirect payment while a transaction between downstream and upstream water users for water allocations is an example of a direct payment. However, where indirect payment mechanisms are often plagued by their ambiguous impact on conservation incentives, complex requirements for implementation, and the mismatch between the scale of management and scale of impact on the ecosystem, direct payment mechanisms can be carefully designed to cater to the requirement for protecting the whole suite of biodiversity or specific components of biodiversity.

In many cases, a change of institutions is all that is needed in order to give economic incentives. Accordingly, institutions were singled out as one important type of socioeconomic arrangement directly associated with economic incentives which is likely to be a major determinant of the vulnerability or success of biodiversity conservation. Economic incentives, institutions and their link have already massively been addressed in the literature but at smaller scales than those proposed in this paper. Any developing research programmes in this general area could meaningfully utilise the framework and the tools supplied in this paper, in a multiplicity of ways. For instance there exist multiple potentially productive and feasibly examinable research themes between the various elements in the framework, all the while bearing its holistic context in mind. Several of the tools listed are in widespread or emergent use in the subcontinent, and actual evidence can be collected and even further experiments fruitfully designed, again using the framework as a more comprehensive backdrop for interconnections. Approaches recognising the complexity of influences in bioregional systems, and at the same time recommending and/or examining practical interventions for incentivisation, are likely to yield the most leverage towards sustainable conservation in bioregions.

\section{References}

Agrawal, A., \& Gibson, C. (1999). Enchantment and disenchantment: The role of community in natural resource conservation. World Development, 27(4), 629-649. http://dx.doi.org/10.1016/S0305-750X(98)00161-2

Agrawal, A., \& Oström, E. (2001). Collective action, property rights and decentralization in resource use in India and Nepal. Politics and Society, 29(4), 485-514. http://dx.doi.org/10.1177/0032329201029004002

Ashley, C. (1996). Incentives affecting biodiversity conservation and sustainable use: the case of land use options in Namibia. Retrieved from http://www.met.gov.na/publications/research/rdp_0013.pdf

Aumann, R. J. (1997). Rationality and bounded rationality. Games and Economic Behavior, 21, 2-14. http://dx.doi.org/10.1006/game.1997.0585 
Bateman, I. J., Hanemann, M., Hett, T., Lee, M., Jones-Lee, M., Carson, R., ... Swanson J. (2002). Economic Valuation with Stated Preferences Techniques: A Manual. Cheltenham: Edward Elgar.

Biggs, H. C., \& Rogers, K. H. (2003). An adaptive system to link science, monitoring, and management in practice. In Du Toit, J. T., Rogers, K. H., \& Biggs, H. C. (Eds.), The Kruger experience: ecology and management of savanna heterogeneity (pp. 59-80). Washington, Island Press.

Biggs, R., Bohensky, E., Desanker, P. V., Fabricius, C., Lynam, T., Misselhorn, A. A., ... Van Jaarsveld, A. S. (2004). Nature supporting people: the Southern African Millennium Ecosystem Assessment (integrated report). Council for Scientific and Industrial Research, Pretoria.

Blignaut, J. N., \& Aronson, J. (2008). Getting serious about maintaining biodiversity. Conservation letters, 1(1), 12-17. http://dx.doi.org/10.1111/j.1755-263X.2008.00006.x

Bohnet, I., \& Smith, D. M. (2007). Planning future landscapes in the Wet Tropics of Australia: A social-ecological $\begin{array}{lllll}\text { framework. Landscape } \quad \text { and } & \text { 137-152. }\end{array}$ http://dx.doi.org/10.1016/j.landurbplan.2006.07.001

Convention on Biological Diversity. (1993). Retrieved from http://www.biodiv.org/convention/articles.asp

Cowling, R. M. (2005). The process of mainstreaming: Conditions, constraints and prospects. In Petersen, C., \& Huntley, B. J. (Eds.), Mainstreaming biodiversity in production landscapes (pp. 18-25). Washington, DC. Global Environment Facility.

DeFries, R., Hansen, A., Turner, B. L., Reid, R., \& Liu, J. (2007). Land use change around protected areas: management to balance human needs and ecological function. Ecological Applications, 17, 1031-1038. http://dx.doi.org/10.1890/05-1111

Department of Environmental Affairs and Tourism. (2004). National Environmental Management: Biodiversity Act 10 of 2004. Pretoria, Department of Environmental Affairs and Tourism.

Department of Environmental Affairs and Tourism. (2007). Guideline regarding the determination of bioregions and the preparation and publication of bioregional plans. Pretoria, Department of Environmental Affairs and Tourism.

DFID. (1999). Sustainable livelihoods guidance sheets. Retrieved from http://www.livelihoods.org

Emerton, L. (2001a). The nature of benefits and the benefits of nature. Why wildlife conservation has not economically benefited communities in Africa. In Hulme, D., \& Murphree, M. (Eds.), African wildlife and livelihoods. The promise and performance of community conservation. Oxford: James Currey Ltd.

Emerton, L. (2001b). Community-based incentives for nature conservation. Retrieved from http://economics.iucn.org

Fabricius, C., Koch, E., Magome, H., \& Turner, S. (2004). Rights, resources and rural development: community-based natural resource management in Southern Africa. London: Earthscan.

Gans, J. S. (1996). On the impossibility of rational choice under incomplete information. Journal of Economic Behavior and Organization, 29, 287-309. http://dx.doi.org/10.1016/0167-2681(95)00064-X

Grundy, I. M., \& Michell, N. (2004). Participatory forest management in South Africa. In Lawes, M. J., Eeley, H. A. C., Shackleton, C. M., \& Geach, B. G. S. (Eds.), Indigenous forests and woodlands in South Africa: policy, people and practice (pp. 679-712). Durban: University of KwaZulu-Natal Press.

Gunderson, L. H., \& Holling, C. S. (2002). Panarchy: understanding transformations in human and natural systems. Washington DC: Island Press.

Gupta, A. K. (1999). Science, sustainability and social purpose: barriers to effective articulation, dialogue and utilization of formal and informal science in public policy. International Journal of Sustainable Development, 2(3), 368-371.

Hansen, A. J., \& DeFries, R. (2007). Ecological mechanisms linking protected areas to surrounding lands. Ecological Applications, 17, 974-988. http://dx.doi.org/10.1890/05-1098

Hertzler, G. (2007). Adapting to Climate Change and Managing Climate Risks by Using Real Options. Australian Journal of Agricultural Research, 58(2007), 985-992. http://dx.doi.org/10.1071/AR06192

Knight, A. T., Cowling, R. M., Rouget, M., Balmford, A., Lombard, A. T., \& Campbell, B. M. (2008). Knowing but not doing: Selecting priority conservation areas and the research-implementation gap. Conservation Biology, 22(3), 610-617. http://dx.doi.org/10.1111/j.1523-1739.2008.00914.x 
Kumar, P. (2005). Market for ecosystem services. International Institute for Sustainable Development Report. Retrieved from http://www.iisd.org

Lebel, L., Anderies, J. M., Campbell, B., Folke, C., Hatfield-Dodds, S., Hughes, T. P., \& Wilson, J. (2006). Governance and the capacity to manage resilience in regional social-ecological systems. Ecology and Society, 11(1). Retrieved from http://www.ecologyandsociety.org/vol11/iss1/art19

Meinzen-Dick, R., \& Adato, M. (2001). Applying the sustainable livelihoods framework to impact assessment. Integrated Natural Resource Management. Retrieved from www.ciat.cgiar.org/inrm/workshop2001/docs/titles/4-2BPaperRMeinzen-Dick.pdf

Millennium Ecosystem Assessment. (2003). Ecosystems and human wellbeing: Current state and trends. Retrieved from http://www.millenniumassessment.org

Millennium Ecosystem Assessment. (2005). Ecosystems and human well-being: synthesis. Washington DC: Island Press.

Oström, E. (1990). Governing the commons: the evolution of institutions for collective action. Cambridge: Cambridge University Press. http://dx.doi.org/10.1017/CBO9780511807763

Reid, H., \& Turner, S. (2004). The Richtersveld and Makuleke contractual parks in South Africa: win-win for communities and conservation? In Fabricius, C., Koch, E., Magome, H., \& S. Turner (Eds.), Rights, resources and rural development: community-based natural resource management in Southern Africa (pp. 223-234). London: Earthscan.

Scoones, I. (1998). Sustainable rural livelihoods: a framework for analysis. IDS Working Paper 72. Retrieved from http://www.sarpn.org.za/rpp/land.php

Secretariat of the Convention on Biological Diversity. (2001). Assessment, conservation and sustainable use of forest biodiversity. CBD Technical Series Report No. 3, Montreal.

Sent, E. (2004). The legacy of Herbert Simon in game theory. Journal of Economic Behavior and Organization, 53, 303-317. http://dx.doi.org/10.1016/j.jebo.2002.10.006

Seydack, Armin (Dr). Personal communication. SANParks Knysna Office, South Africa.

Shyamsundar, P., Araral, E., \& Weeraratne, S. (2005). Devolution of resource rights, poverty and natural resource management: A review. Environment Economic Series No. 104. Washington DC, World Bank Environment Department.

Tisdell, C. A. (2004). Economic incentives to conserve wildlife on private lands: analysis and policy. The Environmentalist, 24, 153-163. http://dx.doi.org/10.1007/s10669-005-6049-9

Willis, C. B. (2004). Policy frameworks pertaining to the conservation and sustainable use of forests and woodlands in South Africa. In Lawes, M. J., Eeley, H. A. C., Shackleton, C. M., \& Geach, B. G. S. (Eds.), Indigenous forests and woodlands in South Africa: policy, people and practice (pp. 77-107). Durban: University of KwaZulu-Natal Press.

World Resources Institute. (2005). Resource tenure and property rights: access and ownership. Retrieved from http://www.grida.no/wrr/pdf/wrr05_ch3.pdf

\section{Notes}

Note 1. According to the Convention on Biological Diversity (1993), "Biological diversity" means the variability amongst living organisms from all sources, including, inter alia, terrestrial, marine, and other aquatic ecosystems and the ecological complexes of which they are part; this includes diversity within species, between species and of ecosystems. "Ecosystems" in turn, means a dynamic complex of plant, animal and micro-organism communities and their non-living environment interacting as a functional unit.

Note 2. Biodiversity targets in the sense used here are quantitative targets that tell us how much of a biodiversity feature needs to be conserved in order to conserve a representative sample of biodiversity pattern and key ecological and evolutionary processes. Targets are expressed as, for example, numbers of hectares of a land class. Biodiversity targets represent thresholds or tipping points beyond which irreversible loss of ecosystem functioning or of species is likely to occur.

Note 3. It should be noted here that the South African Department of Environmental Affairs (DEA)'s concept of bioregion, defined in South Africa's National Environmental Management: Biodiversity Act (Act 10 of 2004), 
contains "whole or several nested ecosystems and is characterized by its landforms, vegetation cover, human culture and history". Such delineated bioregions are specifically proclaimed. The principles developed in this paper generally apply to any chosen bioregion definition (Department of Environmental Affairs, 2004; Department of Environmental Affairs, 2007).

Note 4. Positive economic incentives reward actors for complying with required actions while negative economic incentives punish actors for non-compliance.

Note 5. Mathematically, this framework can be represented at the aggregate level as a system of the following two simultaneous equations: Biodiversity conservation $=f($ land use mosaic); Land use mosaic $=g$ (values, social factors, technological factors, ecological factors, economic factors, political factors $\mid$ economic approaches used by economic agents) and the following reduced form equation: Biodiversity conservation $=h$ (values, social factors, technological factors, ecological factors, economic factors, political factors | economic approaches used by economic agents).

Note 6. There might be legal and trade limitations to the operationalization of the bioregion model as proposed. For example, it is not unimaginable that veterinary non-tariff trade restrictions could result in dramatic differences in game product prices inside and outside diseased areas within the same bioregion. The legal framework might also be such that certain areas are precluded from carrying out certain activities which our framework might predict as the most suitable land use. Thus, legal and trade limitations could effectively act to define several sub-bioregions with different optimal choices from the ones envisaged by our framework.

Note 7. The latter is of particular significance to developing countries, where significant trade-offs exist between conservation or restoration of ecosystem functions and processes and economic development, and decisions often go the way of big corporations (Kumar, 2005).

Note 8 . Thus, economic incentives constitute one way to enhance the values of biodiversity conservation experienced by decision making units but the ability of the decision making units to recognise further stimuli embodied in economic incentives constitutes another way to enhance the values of biodiversity conservation.

Note 9. To ascertain the true value of land uses involving biodiversity conservation, a combination of direct preference methods, which study behavioral changes in simulated or hypothetical markets, and indirect preference methods such as travel cost models and hedonic valuation, which infer values from data on behavioral changes in actual markets, may be used to capture direct and indirect, tangible and intangible values (Kumar, 2005). However, these methods potentially suffer from a number of biases (see Bateman et al., 2002 for details) which nevertheless could be minimized by careful study design.

Note 10. Agrawal and Oström (2001) provide a useful framework for distinguishing between different types of rights. They suggest that different bundles of rights can be identified in terms of rights of access, withdrawal, management, exclusion and alienation.

Note 11. Investigating the workability of a biodiversity conservation program under the institutions approach requires an analysis of the institutions in a particular jurisdiction and judging whether they are conducive for the workability of the program or whether institutional change ought to be recommended.

Note 12. The empirical evidence on the impacts of devolution on biodiversity conservation, suggests that where the opportunity costs and transaction costs of CBNRM outweigh their benefits, CBNRM programs do not result in enhanced biodiversity conservation (Shyamsundar et al., 2005). The evidence also suggests that CBNRM programs create public goods but they do not specifically create incentives for those who conserve, nor do they punish households that engage in activities inconsistent with the objectives of biodiversity conservation (e.g. poaching and other illegal activities). There is thus an emerging concern that communities do not necessarily link these tangible benefits to the decision to conserve. It appears that whether CBNRM programs have an impact on biodiversity conservation could be influenced by the household's perception of the distinction between community and household benefits; and how these relate to the biodiversity supplying these benefits. That said, there is however some strong evidence to the effect that CBNRM has positive impacts of reduced evidence of poaching; improved perceptions, stronger rights and reduced conflicts with the greater ecosystem surrounding protected areas. The existing empirical evidence suggests that factors such as congruence between clearly defined resource and governance boundaries, congruence between appropriation and provision rules and local conditions, collective choice arrangements, localised monitoring, graduated sanctions, rapid access to low cost conflict resolution mechanisms, minimum recognition of rights by government authorities, and governance activities being organised in multiple layers of nested enterprises in synchrony with resource complexity can contribute to the better performance of CBNRM (Oström, 1990). 